\title{
Prevalence and impacts of animal trypanosomosis in Vogan sheep and Djallonke sheep in southern of Togo
}

\author{
Guiguigbaza-Kossigan Dayo, Essodina Talaki, Balabadi Dao, Kokouvi Soedji, Zakaria Bengaly \& \\ Chia Valentine Yapi-Gnaore
}

Guiguigbaza-Kossigan Dayo : PhD, Maitre de recherche en génétique animale, Togolais, Centre International de Recherche-Développement sur l'Elevage en zone Subhumide (CIRDES), 01 BP 454 Bobo-Dioulasso 01, Burkina Faso, Tel : (00226) 708556 49. / Institut du Sahel (INSAH/ CILSS), BP: 1530 Bamako Mali, Email : charlesdayo@yahoo.fr

Essodina Talaki : Doctorat Unique, Maitre de Conférences, Togolais, Ecole Supérieure d’Agronomie, Université de Lomé (ESA/UL), Email : talakiessodina@yahoo.fr

Balabadi Dao : Master, Togolais, Institut Togolais de Recherche Agronomique (ITRA), Lomé, Togo Email : balabadidao@gmail.com

Kokouvi Soedji : PhD, Togolais, Directeur Général de l’Institut National de Formation Agricole (INFA), BP : 401 Kpalimé, TOGO. Email : kokouvisoedji@yahoo.fr

Zakaria Bengaly : Doctorat/HDR, Chargé de recherche en Parasitologie-Epidémiologie, Burkinabé, Directeur scientifique du Centre International de Recherche-Développement sur l'Elevage en zone Subhumide (CIRDES), 01 BP 454 Bobo-Dioulasso 01, Burkina Faso. Email : zbengaly1@gmail.com

Chia Valentine Yapi-Gnaore : PhD, Directrice de recherche en zootechnie, Ivoirienne, Directrice Générale du Centre International de Recherche-Développement sur l'Elevage en zone Subhumide (CIRDES), 01 BP 454 Bobo-Dioulasso 01, Burkina Faso. Email : evayapi11@yahoo.fr

DOI: $10.25518 / 2295-8010.1629$

\section{Résumé :}

\section{Prévalences et impacts de la trypanosomose animale chez le mouton Vogan et le} mouton Djallonke au sud du Togo

L'objectif de cette étude était de déterminer les prévalences des trypanosomoses animales et leurs effets sur les valeurs de l'hématocrite dans les populations du Mouton de Vogan (MV) et du Mouton Djallonké (MD) dans deux régions administratives du sud du Togo (Région Maritime et Région des Plateaux). Des échantillons de sang de 206 échantillons (104 MV et 102 MD) ont été analysés par l'observation microscopique de la couche leucocytaire, la PCR et l'ELISA indirect. En utilisant les trois techniques de diagnostic, la prévalence était de $24,51 \%$ pour les moutons Djallonke et de 20,19\% pour les moutons Vogan, avec une nette prédominance des infections à Trypanosoma vivax dans la zone d'étude. Le facteur « localité » a influencé de manière significative la prévalence des infections trypanosomiennes et l'hématocrite des animaux. Les prévalences les plus élevées ont été obtenues dans les cantons de Dagbatchi et Sevagan et sont associés aux hématocrites les plus faibles. 
Prevalence and impacts of animal trypanosomosis in Vogan sheep and Djallonke ...

Aucune différence significative n'a été observée entre les hématocrites des MV et ceux des MD dans la région Maritime. Il apparaît que même avec un phénotype sahélien, la race de Mouton de Vogan est bien adaptée à son environnement et a développé un certain degré de trypanotolérance similaire à celle du Mouton Djallonké. Toutefois, les moutons Djallonké de la Région Maritime (préfecture de Vo) seraient moins trypanotolérants comparativement à ceux provenant de la Région des Plateaux.

Ces résultats montrent que les stratégies d'amélioration génétique des moutons devraient prendre en compte les trypanosomoses animales.

\begin{abstract}
:
The aim of this study was to estimate the prevalence of animal trypanosomosis and its impact on the Packed red Cell Volume (PCV) in Vogan sheep (VS) and Djallonke sheep (DS) in two administrative regions of southern-Togo (Maritime and Plateau Regions). A total of 206 samples (104 VS and 102 DS) were analysed by microscopic observation of buffy coat, PCR and indirect ELISA. Using the three diagnostic techniques, the prevalence was $24.51 \%$ in Djallonke sheep and $20.19 \%$ in Vogan sheep with a clear predominance of Trypanosoma vivax infection.

Geographical location (canton) influenced significantly the prevalence of trypanosome infections and the PCV; the highest recorded prevalence was obtained in Dagbatchi and Sevagan locations, associated with the lowest PCV.

No significant difference was observed between PCV of VS and those of DS in Maritime Region. We concluded that even with a phenotype of Sahelian sheep, VS is well adapted in this area and has developed a certain degree of trypanotolerance similar to DS. However, Djallonke sheep in the Maritime Region (Vo Prefecture) might have become less trypanotolerant comparatively to those originating from the Plateau Region.
\end{abstract}

These results could be used to update the epidemiological situation of trypanosomosis in this region and showed that the sheep genetic improvement strategies should take into account animal trypanosomosis.

\title{
Introduction
}

In Togo, Vogan sheep (VS), a local breed commonly called "Mouton de Vogan" is numerically the second sheep breed behind the West African Dwarf sheep also called "Djallonke sheep" (DS) known throughout West Africa. VS is a crossbreed between Sahelian sheep and West African Dwarf sheep $(4 ; 13)$. The breeding of VS is essentially located in the south-eastern part of Togo and is used for meat production. Its breeding area is characterized by a sudano-guinean climate with two rainy seasons (mid-March to mid-July and mid-September to mid-November) and two dry seasons (mid-November to mid-March and mid-July to mid-September). This climate is favourable to vectorborne parasitic diseases (tsetse and African Animal Trypanosomosis (AAT), ticks and tick-borne diseases). Vogan sheep shares this tsetse-infested area with Djallonke sheep that is considered a trypanotolerant breed $(2 ; 4 ; 21)$. In sheep and goats, trypanotolerance is less pronounced than in cattle and is called "resilience". Trypanotolerant breeds are also more resistant to infestation by gastrointestinal nematodes. In endemic areas of AAT, goats are less infected than sheep (25).

In West Africa, the population of trypanotolerant small ruminants is Djallonke sheep while the Sahelian and exotic sheep breeds represent the trypanosusceptible populations. West African Dwarf 
goats are less trypanotolerant than Djallonke sheep (21). In natural conditions, Djallonke sheep and West African Dwarf goat breeds express resilience to AAT. In Djallonke-Sahelian crossbred sheep, Goossens et al. (22) observed higher parasitaemia, a shorter prepatent period and lower antibody responses compared to pure Djallonke sheep. However, differences between the two breeds on the Packed red Cell Volume (PCV) reduction and weight gain were not observed. On the contrary, Djallonke-Sahelian crossbred sheep showed a higher potential to intensify mutton production as compared to the pure Djallonke sheep. In a recent study conducted in the same area as the present study, Talaki et al. (33) reported the presence of Trypanosoma vivax, Trypanosoma congolense and Trypanosoma brucei brucei in cattle with a clear predominance of $T$. vivax. Under controlled conditions, Bengaly et al. (7) showed that small ruminants were more resilient to T. vivax than T. congolense. Indeed, the authors reported better resilience of Djallonke sheep and goats compared to Sahelian sheep and goats for T. vivax infection while no significant difference was observed between the breeds of the two species for T. congolense infection. The authors linked the higher resilience of Djallonke breeds for T. vivax infection to innate and / or acquired physiological mechanisms.

Up to now, no study has been conducted on AAT in Vogan sheep populations. Thus, the present study aimed at: i) estimating the parasitological, serological and molecular prevalence of animal trypanosomosis in Vogan sheep and Djallonke sheep in the prefectures of Vo (Maritime administrative Region), Agou and Kloto (Plateau administrative Region); ii) comparing the prevalence between VS and MD in Prefecture Vo and between the two subpopulations of DS (subpopulation from the prefecture of Vo and subpopulation in the prefectures of Agou and Kloto where VS is absent); iii) assessing the impact of AAT on animal health through the measurement of the degree of anemia.

\section{Materials and methods}

\section{Study area}

The study was conducted in three prefectures of two administrative regions of Togo: prefecture of Vo in south-eastern Togo (Maritime Region) for VS and DS; and in prefectures of Kloto and Agou in south-western Togo (Plateau Region) for DS (figure 1). 


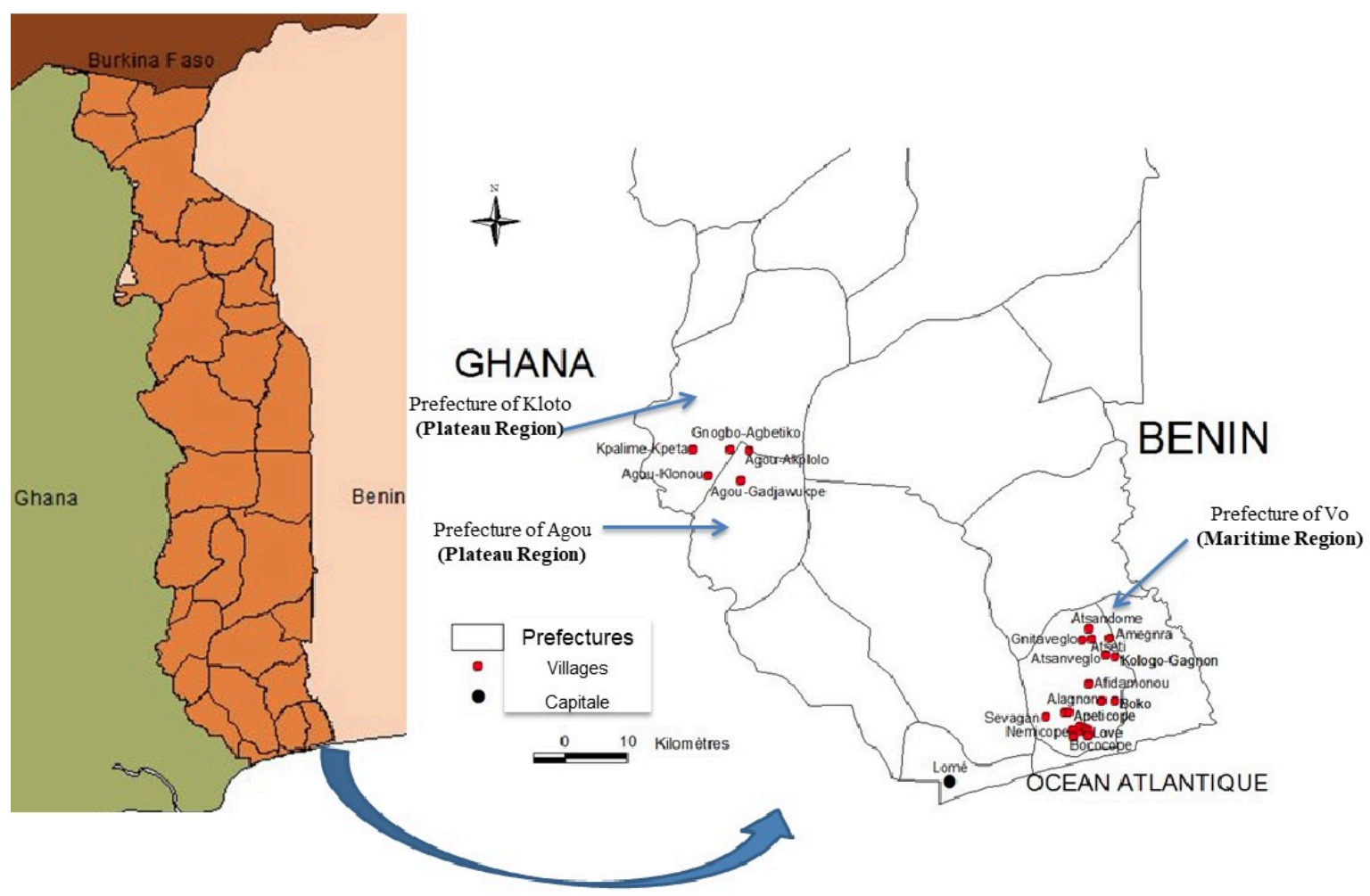

Figure 1: Study area

The Djallonke sheep in the prefectures of Agou and Kloto in Plateau Region were used as "reference of trypanotolerant population" since the Djallonke sheep in this region is considered to be genetically more conserved than those from the prefecture of Vo.

\section{Animal sampling and blood collection}

A total of 206 animals (104 VS and 102 DS) in 65 flocks were randomly selected in 12 cantons of three prefectures (Vo, Agou and Kloto) (Table 1). Among the 206 animals sampled, 160 (77.67\%) were females and 46 (22.33\%) males. In each flock, 1 to 10 unrelated individuals were selected according to the size of the flocks. Blood was taken from the jugular vein into vacutainer tubes containing disodium salt of Ethylene Diamine Tetra-Acetate (EDTA) for microscopic examination within a maximum of 4 hours after blood collection, and in dry tubes for serum collection for serological analysis. 
Table 1: Sample size per location Region, prefecture and canton) and per breed (DS: Djallonke sheep and VS: Vogan sheep)

\begin{tabular}{|c|c|c|c|c|}
\hline Region & Prefecture & Canton & Djallonke sheep & Vogan sheep \\
\hline \multirow[t]{7}{*}{ Maritime } & Vo & Dagbatchi & 16 & 0 \\
\hline & Vo & Dzreko & 24 & 0 \\
\hline & Vo & Koutime & 4 & 13 \\
\hline & Vo & Sevagan & 0 & 20 \\
\hline & Vo & Togoville & 6 & 49 \\
\hline & $\mathrm{V}$ & Vogan & 0 & 12 \\
\hline & Vo & Wogba-Vogan & 0 & 10 \\
\hline \multirow[t]{6}{*}{ Plateau } & Agou & Akplolo & 6 & 0 \\
\hline & Agou & Gadja & 13 & 0 \\
\hline & Agou & Gnogbo-Agbetiko & 10 & 0 \\
\hline & Agou & Klonou & 13 & 0 \\
\hline & Kloto & Tove_Kpeta & 10 & 0 \\
\hline & & Total & 102 & 104 \\
\hline
\end{tabular}

\section{Parasitological examination}

For parasitological analysis, microscopic examination for trypanosomes using the Buffy Coat Technique (BCT) (27) and molecular diagnosis by polymerase chain reaction (PCR) technique for trypanosome DNA detection were used. The Packed red Cell Volume percentage (PCV) was estimated for each sample in a microhaematocrit tube after centrifugation for 5 minutes at 12,500 rpm. The level of parasitaemia was scored according to the buffy coat/phase contrast technique (29). The trypanosome species were identified by their movement and morphology on a phasecontrast microscope with a X 40 objective lens.

Buffy coat of all samples (parasitologically positive and negative for pathogenic trypanosomes) were collected into a $0.5 \mathrm{ml}$ micro tube, containing $30 \mu \mathrm{l}$ of sterile distilled water and stored at $-20^{\circ} \mathrm{C}$. For PCR, DNA was extracted with chelex ${ }^{\circledR} 100$ (31) and tested with specific primers for T. vivax, $T$. congolense (savannah type) and T. brucei $(17,24)$. 


\section{Antibody detection by indirect Enzyme-Linked ImmunoSorbent Assay (ELISA)}

Blood from the jugular vein collected in dry tubes (without anticoagulant) was used for serum collection after coagulation. Serum samples were collected in Eppendorf tubes and stored at $-20^{\circ} \mathrm{C}$ until analysis. Three indirect antibody ELISAs, using respectively T. vivax, T. congolense and $T$. brucei antigens, were performed on each sample, according to Desquesnes et al. (16). For each system of antibody ELISA, the optical density results were expressed in Percentage of Positivity (PP) as previously described (14); the positive threshold of the test had been fixed as the mean PP of negative reference samples plus three standard deviations (16). Since those serological tests are not species-specific for different Trypanosoma species, we used, for the interpretation of serological results, the maximum scores of positivity (15). A sample was considered positive for the species of trypanosome that had the highest percentage of positivity. The fact that the intensity of the homologous reaction is higher than the heterologous ones has been demonstrated at several instances $(14 ; 15 ; 20)$. The three ELISAs combined and evaluated under controlled conditions exhibited sensitivities > 90\% in experimentally infected sheep and specificities \&gt; $99 \%$ in noninfected animals (16).

\section{Statistical analysis}

Statistical analysis was carried out using R software 3.1.0 (30). The parasitological prevalence was calculated as the percentage of positive cases, estimated by the combination of BCT examination results and PCR analysis. The same calculation was applied to determine the serological prevalence. The serological prevalence was calculated using the maximum scores of positivity. Analysis of variance and t-test were used to compare: i) the PCV of infected and non-infected animals, ii) the PCV of animals infected with T. congolense and animals infected with T. vivax, iii) the mean PCV between the sheep breeds, iv) the PCV of the Djallonke population of the Maritime Region (prefecture of Vo) and the Djallonke population of the Plateau Region (Kloto and Agou). The same analyses were used to compare the age of serologically positive and negative animals.

The overall prevalence is calculated as the number of individuals positive in at least one diagnostic test divided by the number of individuals sampled in each administrative region.

\section{Results}

\section{Prevalence of trypanosomes}

The buffy coat examination showed only 2 infected animals with_T. vivax_in Vogan sheep (prevalence of $1.92 \%)$. No infection was found in Djallonke sheep using the buffy coat technique. Using the PCR technique, the prevalence for all trypanosome species reached $12.75 \%$ in DS and $16.35 \%$ in VS (Table 2). 
Table 2: Prevalence of infection per trypanosome species and overall prevalence using PCR (TC : T. congolense ; TV : T. vivax; TB : T. brucei sl)

\begin{tabular}{|c|c|c|c|c|c|c|c|c|c|}
\hline $\begin{array}{l}\text { Sheep } \\
\text { breeds }\end{array}$ & $\begin{array}{l}\text { Sample } \\
\text { size }\end{array}$ & $\begin{array}{l}\text { No. of T. } \\
\text { congolense } \\
\text { infections }\end{array}$ & $\begin{array}{l}\text { Prevalence } \\
\text { of T. } \\
\text { congolense } \\
\text { infection }\end{array}$ & $\begin{array}{l}\text { No. of T. } \\
\text { vivax } \\
\text { infections }\end{array}$ & $\begin{array}{l}\text { Prevalence } \\
\text { of T. vivax } \\
\text { infection }\end{array}$ & $\begin{array}{l}\text { No. of T. } \\
\text { brucei } \\
\text { infections }\end{array}$ & $\begin{array}{l}\text { Prevalence } \\
\text { of T. } \\
\text { brucei sl } \\
\text { infection }\end{array}$ & $\begin{array}{l}\text { No. of } \\
\text { TC+TV+TB } \\
\text { infections }\end{array}$ & $\begin{array}{l}\text { Overall } \\
\text { prevalence } \\
\text { using PCR }\end{array}$ \\
\hline $\begin{array}{l}\text { Djallonke } \\
\text { sheep }\end{array}$ & 102 & 0 & 12 & 11.76 & 1 & 0.98 & 13 & 12.75 & \\
\hline $\begin{array}{l}\text { Vogan } \\
\text { sheep }\end{array}$ & 104 & 0 & 13 & 12.50 & 6 & 5.77 & 17 & 16.35 & \\
\hline
\end{tabular}

The serological prevalence is presented in Table 3.

Table 3: Seroprevalence of infection per trypanosome species and overall serological prevalence(TC : T. congolense ; TV : T. vivax; TB : T. brucei sl)

\begin{tabular}{|c|c|c|c|c|c|c|c|c|c|}
\hline $\begin{array}{l}\text { Sheep } \\
\text { breeds }\end{array}$ & $\begin{array}{l}\text { Sample } \\
\text { size }\end{array}$ & $\begin{array}{l}\text { No. of T. } \\
\text { congolense } \\
\text { infections }\end{array}$ & $\begin{array}{l}\text { Prevalence } \\
\text { of } \mathrm{T} \text {. } \\
\text { congolense } \\
\text { infection }\end{array}$ & $\begin{array}{l}\text { No. of T. } \\
\text { vivax } \\
\text { infections }\end{array}$ & $\begin{array}{l}\text { Prevalence } \\
\text { of T. vivax } \\
\text { infection }\end{array}$ & $\begin{array}{l}\text { No. of T. } \\
\text { brucei } \\
\text { infections }\end{array}$ & $\begin{array}{l}\text { Prevalence } \\
\text { of T. } \\
\text { brucei sl } \\
\text { infection }\end{array}$ & $\begin{array}{l}\text { No. of } \\
\text { TC+TV+TB } \\
\text { infections }\end{array}$ & $\begin{array}{l}\text { Overall } \\
\text { serological } \\
\text { prevalence } \\
\text { (TC, TV } \\
\text { and TB) }\end{array}$ \\
\hline $\begin{array}{l}\text { Djallonke } \\
\text { sheep }\end{array}$ & 102 & 10 & 9.80 & 12 & 11.76 & 1 & 0.98 & 23 & 22.55 \\
\hline $\begin{array}{l}\text { Vogan } \\
\text { sheep }\end{array}$ & 104 & 3 & 2.88 & 10 & 9.62 & 0 & 0 & 13 & 12.50 \\
\hline
\end{tabular}

Using the three diagnostic techniques (BCT, ELISA and PCR), the prevalence was $24.51 \%$ in Djallonke sheep and 20.19\% in Vogan sheep with a clear predominance of Trypanosoma vivax infection in the study area.

\section{Packed red Cell Volume analysis}

The minimum and maximum observed PCV per sheep breed are presented in Table 4. 
Prevalence and impacts of animal trypanosomosis in Vogan sheep and Djallonke ...

Table 4 : Mean PCV (Standard Deviation), minimum and maximum value of PCV per sheep population (a,bMean PCVs with different superscript letters are significantly different (P $>$ 0.05))

\begin{tabular}{llll}
\hline Sheep breeds & $\begin{array}{l}\text { Mean PCV (Standard } \\
\text { Deviation) }\end{array}$ & $\begin{array}{l}\text { Minimum } \\
\text { PCV }\end{array}$ & $\begin{array}{l}\text { Maximum } \\
\text { PCV }\end{array}$ \\
\hline Vogan sheep & $29(5.21) \mathrm{b}$ & 14 & 32 \\
Djallonke sheep in Maritime Region & $27.78(5.86) \mathrm{b}$ & 11 & 39 \\
Djallonke sheep in Plateau Region & $31.88(4.09) \mathrm{a}$ & 24 & 39 \\
$\begin{array}{l}\text { Djallonke sheep in both Maritime and Plateau } \\
\text { Regions }\end{array}$ & $29.87(5.42) \mathrm{b}$ & 11 & \\
\hline
\end{tabular}

No significant difference ( $p=0.241$ ) was observed between the PCV of VS and DS (when we combine data from Maritime Region and Plateau Region) or between VS and DS in the same area ( $p$ $=0.214)$. However, the PCVs of VS were significantly lower than those of well-conserved DS from the Plateau Region $(p<0.001)$. Similarly, the PCVs of DS of the Plateau Region were significantly greater than those of the DS in the prefecture of Vo $(p<0.001)$.

The infection status of the animals had an effect on the PCVs. Indeed, in the two sheep breeds, the average PCV of positive animals was significantly lower than that of negative animals $(p<0.01)$ (Table 5). 
Table 5: Comparative mean PCV (SD: Standard Deviation) of positive and negative animals in each breed using the Student t-test.

\begin{tabular}{llll}
\hline Breed names & $\begin{array}{l}\text { Mean PCV of animals } \\
\text { detected positive for } \\
\text { trypanosome infection } \\
\text { (SD) }\end{array}$ & $\begin{array}{l}\text { Mean PCV of animals } \\
\text { detected negative for } \\
\text { trypanosome infection } \\
\text { (SD) }\end{array}$ & $\begin{array}{l}\text { Comparison between mean PCV } \\
\text { of positive and negative animals } \\
\text { in each breed (P-value) }\end{array}$ \\
\hline $\begin{array}{l}\text { Vogan Sheep } \\
\text { 25.05(5.37) }\end{array}$ & $30.01(4.69)$ & $\mathrm{P}<0.001$ \\
$\begin{array}{l}\text { Djallonke Sheep in } \\
\text { both Maritime and } \\
\text { Plateau Regions }\end{array}$ & $26.16(6.54)$ & $31.08(4.42)$ & $\mathrm{P}<0.01$ \\
$\begin{array}{l}\text { Djallonke Sheep in } \\
\text { Maritime Region }\end{array}$ & $24.00(6.24)$ & $29.56(4.8)$ & $\mathrm{P}<0.01$ \\
$\begin{array}{l}\text { Djallonke Sheep in } \\
\text { Plateau Region }\end{array}$ & $30.00(5.41)$ & $32.28(3.7)$ & $\mathrm{P}=0.2566$ \\
\hline
\end{tabular}

However, in the Plateau Region (Prefectures of Agou and Kloto), no significant difference was observed between the PCVs of infected and non-infected Djallonke sheep $(p=0,26)$.

\section{Association between mean PCV and prevalence of infection per location}

The cantons of Dagbatchi and Sevagan presented the highest prevalence (combination of BCT, ELISA and PCR results)and consequently the lowest mean PCV (figure 2). The least infected cantons were Klonou (0 \%), Wogba - Vogan (0\%) and Togoville (1.8\%). 


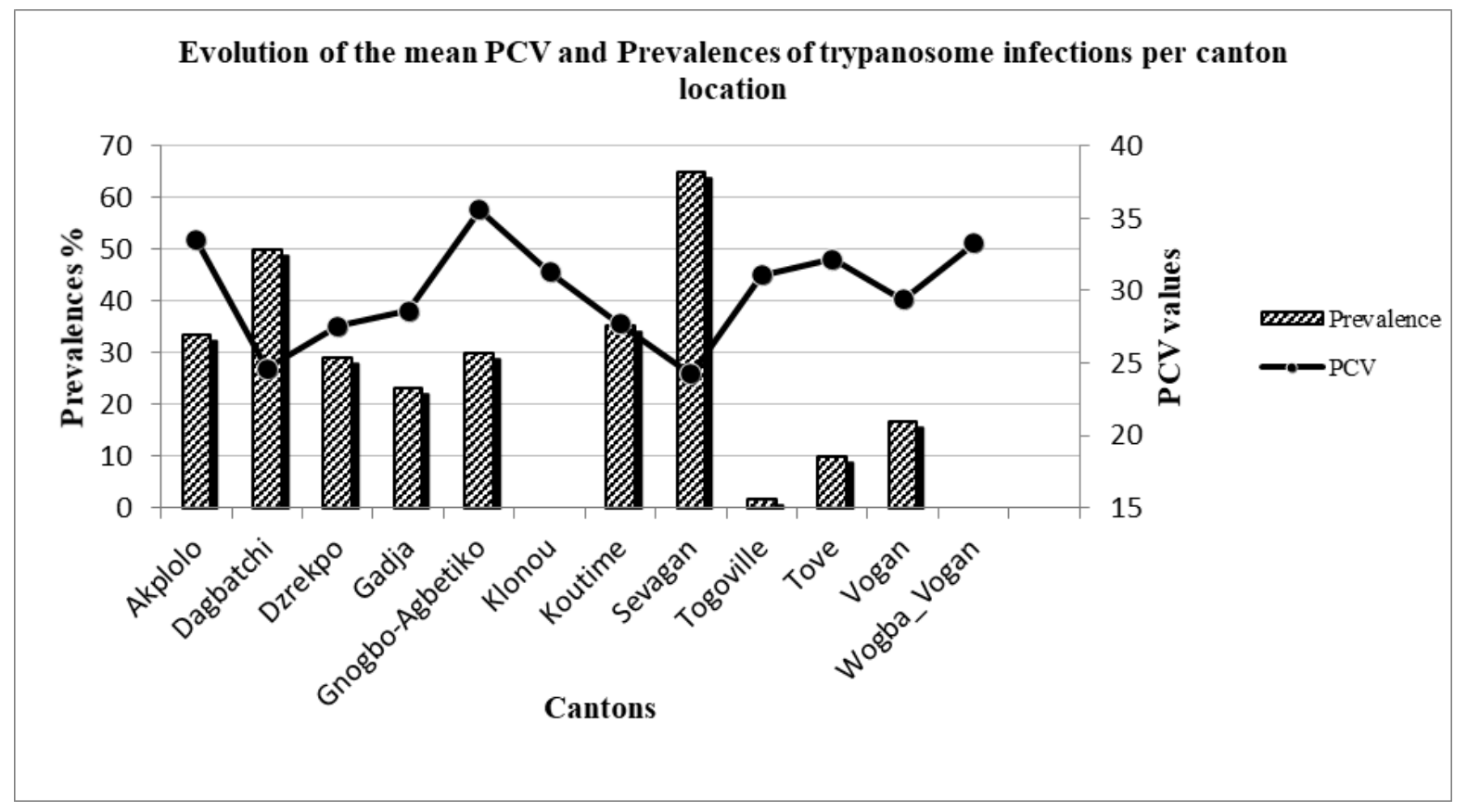

Figure 2: Comparison of the mean PCV and prevalence of trypanosome infections per canton

\section{Discussion}

The objective of this study was to determine the prevalence of animal trypanosomosis in Vogan and Djallonke sheep using 3diagnostic techniques and to measure the impact of trypanosome infection on the PCV in those breeds. Overall,the impact of trypanosomosis in small ruminants has received little attention in West Africa. The scarcity of knowledge about it is even greater in crossbred sheep between trypanotolerant (Djallonke sheep) and trypano-susceptible (Saheliansheep) breeds. Nevertheless, it has been reported that the West African dwarf sheep is trypanotolerant while the Sahelian sheep appears to be trypano-susceptible (19). In Togo, the few studies conducted have shown that Djallonke sheep and Djallonke goat are trypanotolerant $(25 ; 26)$. All the three prefectures included in the current study are suitable for breeding areas (availability of forage and drinking water for animals) but are also a biotope for tsetse flies, vectors of AAT (23).

\section{Parasitological, serological and molecular prevalence}

Parasitological examinations have detected Trypanosoma vivax with a prevalence of $1.92 \%$. T. brucei brucei and T. congolense were not detected on microscopy. This relatively low prevalence is similar to the results reported in the few studies on African animal trypanosomosis in sheep of southern Togo $(25)$ and in cattle $(9 ; 11 ; 28 ; 33)$. The low prevalence observed may also be justified by the season of the survey and the low sensitivity of the buffy coat technique. Indeed,our study was conducted in the dry season (January). During this season,trypanosome transmission is highly localized around the gallery forests where tsetse populations are concentrated. It is also known that trypanosomosis infection is only possible in case of closed and regular contact between animals (hosts) and tsetse (vectors). In our study, animals (VS and DS) were kept at home and did not move near gallery forests. The sensitivity of the BCT is low compared to PCR and ELISA $(12 ; 15)$. 
Furthermore, the high seroprevalence obtained in DS in this study comparatively to the molecular (PCR)prevalence rates could be explained by the endemicity of AAT in the Plateau Region (25) relative to the AAT situation in the Maritime Region. This endemicity results in a large number of DS with detectable antibodies, which increased the overall seroprevalence in Djallonke sheep (24.51\%) compared to Vogan sheep (20.19\%). In the Plateau Region, environmental conditions are more favorable to the development of biological (tsetse flies) and mechanical (tabanid and stomoxys) vectors of animal trypanosomes. In endemic areas, contacts between vectors and hosts occur more frequently so that the hostscan maintain high antibody levels. It is important to note that ELISA allows diagnosis of both active and passive infections where as the BCT and the PCR only detect active infection. In cattle for example, antibodies can persist and be detectable about 2 to 4 months after an active infection $(8 ; 15)$.

It is clear that in southern Togo, T. vivax infections predominate over other trypanosome species in ruminants and the situation has not changed since the work of Mawuena(25). In the Central Region of Togo,T. congolense and T. vivax play an important role in trypanosomosis in ruminants. Indeed, a predominance of T. congolense infection sin sheep and goat populations has been observed in Sokode $(5 ; 6)$ in the Central Region, while in a recent study, Talaki et al. (32) observed a predominance of infections of_T. vivax (88.17\%), T. congolense (10.06\%) and mixed infections(1.78\%) in cattle. The same observations were reported in the Savannah and Kara Regions in cattle populations of northern Togo (34).

\section{Impact of trypanosomosis infections in animals}

Anaemia is one of the important clinical parameters of trypanosome infection and measured by a significant decrease inhaematocrit. In this study,the significant difference $(p<0.01)$ observed between the mean PCV inpositive and negative animals (Table5), both in Djallonke sheep from the prefecture of Vo and Vogan sheep emphasizes the medical and economic importance of trypanosomosis in the Maritime Region as also shown in cattle $(3 ; 10 ; 12 ; 35)$. However, the PCVs of infected and non-infected Djallonke sheep from the prefectures of Agou and Kloto were not significantly different, as opposed to what was observed in Djallonke sheep in the Prefecture of Vo. This observation can be explained by i) the high endemicity of TAA in the prefectures of Agou and Kloto,compared to the prefecture of Vo, ii) Vogan sheep and Djallonke sheep of the prefecture ofVowould be less trypanotolerant compared to the Djallonke sheep from the prefectures of Agou and Kloto oriii) the influence of confounding factors (other parasitic and infectious diseases causing anaemia and the under-nutrition of animals).In fact, helminthosis (particularly Haemonchus contortus), tick-borne diseases and someinfectious diseases (pasteurellosis) can cause anaemia in ruminants $(3 ; 18)$. These confounding factors were not included in the present study. In addition, our study was conducted in January corresponding to the dry season in the southern part of Togo. During this season, the pasture and agricultural products are less available for animals in the Prefecture ofVo compared to the situation observed in the prefectures of Kloto and Agou where the dry season has less impact on the pasture availability for the animals. It is important to note that the locations where the PCVs were low(Dagbatchi cantons and Sevagan) were those with the highest prevalence of trypanosome infections. The two populations of Djallonke sheep (Maritime and Plateau Regions) were analyzed separately in this study in order to capture the effect of agroecological factors on trypanosomosis impacts and to assess whether the Djallonke sheep sharing the same zone with Vogan sheep were more susceptible to AAT or not, in comparison with those of the areas where Vogan sheep is absent (Plateau Region). From our results, it seems that 
Prevalence and impacts of animal trypanosomosis in Vogan sheep and Djallonke ...

Djallonke sheep in the prefecture of Vo in Maritime Region might have become less trypanotolerant by crossbreeding with trypanosusceptible breeds (for example Vogan sheep and other transhumant Sahelian sheep). Although the Vogan sheep phenotypically resemble Djallonke sheep, it is possible that there might be introgression of Vogan genes resulting in a loss of trypanotolerance compared to those originating from the Plateau Region. A genetic characterization of animals from different locations might help to clarify this hypothesis.

\section{Conclusion}

African animal trypanosomosis(AAT)is prevalent in the southern part of Togowith a clear predominance of Trypanosoma vivax.The impact of AATis relatively low in sheep but the situation depends on the sheep breed (DS and VS) and the location(region/prefecture and canton). AAT is endemic in the study area with agro-ecological conditions more favorable tovectors (flies) in the prefectures of Agou and Kloto (Plateau Region) than in the Prefecture of Vo. Consequently, DS of Plateau Region seemed to be more trypanotolerant than those of the Maritime Region and VS. The present study showed that Djallonke sheep in Vo Prefecture might have become less trypanotolerant by crossbreeding with trypanosusceptible breeds. It is possible that there might be introgression of Vogan genes resulting in a loss of trypanotolerance in Djallonke sheep from the prefecture of Vo comparared to those originating from the Plateau Region. In order to clarify this, the animals should be genetically characterized.

Future control strategies of AAT in the two regions require considering these aspects.

\section{Acknowledgements}

This work was carried out through a fruitful collaboration between the Centre International de Recherche-Développement sur l'Elevage en zone Subhumide (CIRDES: International Center of Research and Development on Livestock in Sub humid zone), l'Ecole Supérieure d'Agronomie de l'Université de Lomé (ESA/UL: Agronomy High School of Lome University in Togo) and the Institut Togolais de Recherche Agronomique (ITRA: Togolese Institute for Agronomic Research). Activities were funded by the Union Economique et Monétaire Ouest-Africaine (UEMOA: West African Economic Monetary Union) through its Programme to Support Higher Education (PAES). All technicians and drivers of CIRDES, ITRA and ICAT are kindly acknowledged for their high implication during the cross-sectional survey in the field and laboratory analyses. The authors thank the General Director of the Advices Institute and Technical Support (ICAT) of Togo for the availability of the field personal (Ayawo Defly and Adovi Akue-Kpakpo) for the selection of flocks of sheep and blood collection in the field. Finally, we also acknowledge Dr Ali Kadanga of INFA de Tové, M. Yawo Sename Guede, Agent Villageois d'Elevage (AVE) and Mr. Jean-Luce Kokoye.

\section{Bibliographie}

1. Abebe G. \& Eley, R.M., 1992, Hypothalamic pituitary-adrenal axis responsiveness to insulin-induced hypoglycemia is modified by trypanosome infection in Boran (Bos indicus) cattle. Research in veterinary science, 53, 68-73.

2. Agyemang K., 2005, Trypanotolerant livestock in the context of trypanosomiasis intervention strategies. PAAT, FAO, Rome, Italie, 66 p. 
3. Agyemang K., Rawlings, P., Clifford, D.J., Bojang, N. \& Tamba, A., 1991, Productivity and health parameters of small ruminants in villages of the Gambia. Bull. Anim. Health Prod. Afr., 39, 129-135.

4. Amegee, Y., 1983, Le mouton de Vogan (croisé Djallonké x Sahélien) au Togo. Revue d'élevage et de médecine vétérinaire des pays tropicaux 36 , 1, 79-84.

5. Bastiaensen P., Dorny P., Batawui K., Boukaya A., Napala A. \& Hendrickx G., 2003a, Parasitisme des petits ruminants dans la zone périurbaine de Sokodé, Togo. I. Ovins. Revue d'élevage et de médecine vétérinaire des pays tropicaux, 56 , 1-2, 43-50.

6. Bastiaensen P., Dorny P., Batawui K., Boukaya A., Napala A. \& Hendrickx G., 2003b, Parasitisme des petits ruminants dans la zone périurbaine de Sokodé, Togo. II. Caprins. Revue d'élevage et de médecine vétérinaire des pays tropicaux 56 , 1-2, 51-56.

7. Bengaly Z., Clausen P.H., Boly H., Kanwe A. \& Duvallet G.,1993, Comparaison de la trypanosomose experimentale chez certaines races de petits ruminants au Burkina Faso.Revue d'élevage et de médecine vétérinaire des pays tropicaux 46 , 563-570.

8. Bocquentin R., Very P. \& Duvallet G., 1990, Cinétique des anticorps après traitement trypanocide chez des bovins infectés expérimentalement ou naturellement. Intérêt épidémiologique. Revue d'élevage et de médecine vétérinaire des pays tropicaux 43 , 479-483.

9. Boma S., 2012, Diagnostic préliminaire de la chimiorésistance de Trypanosoma vivax à l'acéturate de diminazène et au chlorure d'isométamidium dans la Région des Savanes au nord du Togo. Mémoire de DEA en Biologie de Développement, Faculté des Sciences, Université de Lomé. 61 p.

10. Cherenet, T., Sani, R.A., Speybroeck, N., Panandam, J.M., Nadzr, S., Van den Bossche, P., 2006. A comparative longitudinal study of bovine trypanosomiasis in tsetse free and tsetse-infested zones of the Amhara Region, northwest Ethiopia. Veterinary Parasitology $140,251-258$.

11. Dao B., Sidibé I., Hendrickx G., Belem A.M.G. \& De La Rocque S., 2008, Impact de la sécheresse et la dégradation des aires protégées sur la répartition des trypanosomiases bovines et de leurs vecteurs dans le bassin versant de l'Oti au Nord du Togo. Revue d'Elevage et de Médecine Vétérinaire des Pays Tropicaux, 61 , 34, 153-160.

12. Dayo G-K., Bengaly Z., Messad S., Sidibe I., Cene B., Cuny G. \& Thevenon S., 2010, Factors influencing the prevalence and the incidence of bovine trypanosomosis in an agro-pastoral area of south-west Burkina Faso. Research in Veterinary Sciences, 88, 470-477.

13. Dayo G-K., Alfa E., Talaki E., Soedji K., Sylla S. \& Dao B., 2015, Caractérisation phénotypique du mouton de Vogan du Togo et relation avec le mouton Djallonké et le mouton sahélien. Animal Genetic Resources, 56, 63-78.

14. Desquesnes M., 1997, Standardisation internationale et régionale des épreuves immunoenzymatiques : méthodes, intérêts et limites. Revue scientifique et technique de l'Office 
Prevalence and impacts of animal trypanosomosis in Vogan sheep and Djallonke ...

International des Epizooties 16, 809-823.

15. Desquesnes M., Michel J-F., De La Rocque S., Solano P., Millogo L., Bengaly Z. \& Sidibe I., 1999, Enquête parasitologique et sérologique (Elisa-indirect) sur les trypanosomes des bovins dans la zone de Sidéragoudou, Burkina Faso. Revue d'élevage et de médecine vétérinaire des pays tropicaux, 52, 223-232.

16. Desquesnes M., Bengaly Z., Millogo L., Meme Y. \& Sakandé H., 2001, The analysis of the cross-reactions occurring in antibody-ELISA or the detection of trypanosomes can improve identification of the parasite species involved. Annals of Tropical Medicine and Parasitology, 95, 141-155.

17. Desquesnes M. \& Davila A.M., 2002, Applications of PCR-based tools for detection and identification of animal trypanosomes: a review and perspectives. Veterinary Parasitology, 109, 213-231.

18. Falla A., Diack A., Diaité A., Seye M. \& d'Ieteren G.D.M., 1999, Tsetse challenge, trypanosome and helminth infection in relation to productivity of village Ndama cattle in Senegal. Veterinary Parasitology, 81, 235 \pm 247

19. Farougou S., Doko A.S., Toko Issakou W. \& Akossou J., 2011, Prévalence des infections trypanosomiennes ovines dans la Commune de Kandi, zone Sud-Guinéenne du Bénin. Annales des Sciences Agronomiques, 15 , 2, 231-242.

20. Ferenc S.A., Stopinski V. \& Courtney C.H., 1990, The development of an enzyme-linked immunosorbent assay for Trypanosoma vivax and its use in sero-epidemiological survey in the eastern Caribbean basin. International Journal for Parasitology, 20, 51-56.

21. Geerts S., Osaer S., Goossens B. \& Faye D., 2009, Trypanotolerance in small ruminants of sub-Saharan Africa. Trends Parasitol, 25, 132-138.

22. Goossens B., Osaer S., Ndao M., Van Winghem J. \& Geerts S., 1999, The susceptibility of Djallonké and Djallonké-Sahelian crossbred sheep to Trypanosoma congolense and helminth infection under different diet levels. Veterinary Parasitology, 85 , 25-41.

23. Hendrickx G, Napala A, Dao B, Batawui D., Bastiaensen P., De Deken R., Vermeylen A., Vercruysse J. \& Slingenbergh J.H.W., 1999, The area-wide epidemiology of bovine trypanosomosis and its impact on mixed farming in subhumid West Africa; a case study in Togo. Vet Parasitol, 84 , 13-31.

24. Masiga D.K., Smyth A.J., Hayes P., Bromidge T. J., \& Gibson, W. C., 1992, Sensitive detection of trypanosomes in tsetse flies by DNA amplification. International Journal for Parasitology, 22 , 7, 909-918.

25. Mawuena K., 1986, Trypanosomose des moutons et des chèvres de race naine Djallonké des régions sud-guinéennes au Togo, Revue d'élevage et de médecine vétérinaire des pays tropicaux, 39 , 3-4, 307-315.

26. Mawuena K., 1987, Haut degré de tolérance à la trypanosomose des moutons et des chèvres de race Naine Djallonké des régions sud-guinéennes du Togo. Comparaison avec 
des bovins trypanotolérants. Revue d'élevage et de médecine vétérinaire des pays tropicaux, $\mathbf{4 0}, 1,55-58$.

27. Murray M., Murray P.K. \& McIntyre W.I.M., 1977, An improved parasitological technique for the diagnosis of African trypanosomiasis. Transactions of the Royal Society of Tropical Medicine and Hygiene, 71, 325-326.

28. N'feide T., 2012, Contribution à l'étude des trypanosomoses animales dans un contexte de chimiorésistance au Togo : cas de la station de recherche d'Avétonou (préfecture d'Agou) et du site PLM (préfecture de Vô) de l'ITRA. Mémoire d'ingénieur agronome, Université de Lomé, $60 \mathrm{p}$.

29. Paris J., Murray M. \& McOdimba F., 1982, A comparative evaluation of the parasitological techniques currently available for the diagnosis of African trypanosomiasis in cattle. Acta Tropica, 39, $307-316$.

30. R Development Core Team, 2014, R: A language and environment for Statistical Computing. R fondation for Statistical Computing. Vienne, Austria.

31. Solano P., Michel J.F., Lefrancois T., De La Rocque S., Sidibe I., Zoungrana A. \& Cuisance D. 1999, Polymerase Chain Reaction as a diagnosis tool for detecting trypanosomes in naturally infected cattle in Burkina Faso. Vet. Parasitol., 86, 95-103.

32. Talaki E., Dao B., Dayo G-K., Alfa E. \& N'feide T., 2014a, Trypanosomoses animales dans la Plaîne de Mô au Togo. International Journal of Biological and Chemical Sciences, 8 , 6 , 2462-2469.

33. Talaki E., Dao B., Dayo G-K., N'feide T. \& Sodji, K., 2014b, Etudes entomologiques et parasitologiques des trypanosomoses bovines dans la préfecture de Vo au Sud du Togo. _Revue Africaine de Santé et de Productions Animales___ 12 , 1, 27-30.

34. Talaki E., Dayo G-K, Akoda K., Dao B., Passaw Babi P., Alfa E., Lombo Y., Boukaya G., Tchamdja E. \& Kpabeba A.D., 2014c, Epidemiology of bovine trypanosomosis in Savannah and Kara regions in Northern Togo. International Journal of Agricultural and Soil Science, 2, 8, 126-131.

35. Van den Bossche P. \& Rowlands G.J., 2001, The relationship between the parasitological prevalence infections in cattle and herd average packed cell volume. Acta Tropica, 78, 163-170.

PDF généré automatiquement le 2023-04-26 16:22:06

Url de l'article : https://popups.uliege.be/2295-8010/index.php?id=1629 